\title{
Utilizing Guessing Games to Enhance Students' Speaking Skill in Authentic Assessment at Grade Nine State Junior High School
}

\author{
Luli Sari Yustina and M. Zaim \\ English Deparment \\ Universitas Islam Negeri Imam Bonjol \\ lulyregar@gmail.com
}

\begin{abstract}
This paper is to discuss the utilizing guessing games in enhancing students' speaking skill in authentic assessment at grade IX State Junior High School 1 Padang. According to Burns and Joyce (1997), speaking is an interactive process to build meaning which covers producing, receiving, and processing information. Widdowson (2011) said speaking is an oral productive skill which happens face to face between speaker and hearer. Assessment is a way with questions to seek and to get the answer about what students should know, what the institution contributes to student growth, how learning can be improved. Callison (1998) states that authentic assessment is an evaluation that consists of various forms of performance measurements reflecting the students' learning, achievement, motivation, and attitudes on instructionally-relevant activities. In this discussion, a way has been chosen is guessing game. Wright (1976) stated Guessing games can be good authentic assessment for speaking skill because it helped students to be active to speak and their friends can guess their games. It also contributes to an easier understanding of their pronunciation. It helped the students got some benefits in guessing games. They can improve their speaking and they can enlarge their vocabulary, can make their pronunciation and intonation better. It supported by Alex Case (2000), guessing game is a game/ an object to guess some kinds of information. It is stated that the games attract students' interest, motivation, stimuli to involve in teaching learning process without any doubtless.
\end{abstract}

Keywords—Utilizing, Guessing Games, Enhancing, Speaking, Authentic Assessment

\section{INTRODUCTION}

Assessment is an ongoing process that encompasses a wide range of methodological techniques. Whenever a student responds to a question, offers a comment, or tries out a new word or structure, the teacher subconsciously makes an appraisal of the student's performance. It is one of the important components in learning process. It describes not only the result of the students' final result but also the process that has been allowed by the students to achieve the result. In other words assessment take part in each stage of the learning process, therefore it is conducted continuously. Every subject needs to be assessed in order to give benefit for both teacher and students: to measure, to judge and to compare students' ability and performance.

Brown (2004: 6) showed the interrelationship among the testing, measurement, assessment, teaching and evaluation. It showed all tests are formal assessment but not all formal assessment is testing. In conventional teaching method that commonly used in assessing is test. It is assumed as the most appropriate way to collect information toward students' ability. In this case, test is used for many times even aims to measure all aspect of students' progress. The test that is mostly chosen by the teacher is paper test such as multiple choice, cloze procedure, fill in the blank and essay. However, theoretically to measure students' ability completely, it is not enough only use test. Since test concern to measure students' final score and does not represent the students' progress during teaching- learning process even it seems a product-oriented.

Speaking is an oral productive skill which happens face to face between speaker and hearer (Widdowson, 2011: 57). It is an interactive process to build meaning which covers producing, receiving, and processing information (Burns and Joyce, 1997 : 26). Speaking is one of the four skills that students should master in learning English as a compulsory subject in all levels of education. Many students regard speaking skill measurement of knowing a language. They define fluency as the ability to speak with others. By learning speaking, the students know the way to express opinions, emotions, feelings and ideas meaningfully.

Authentic assessment gains information of real students' ability as closely as their experiences of the lesson. It is regarded as a comprehensive assessment since it assesses both process and product of learning so that the progress of the students start at the beginning until at the end of activities can be evaluate.

Callison (1998:4) states that authentic assessment is an evaluation that consists of various forms of performance measurements reflecting the students' learning, achievement, motivation, and attitudes on instructionally-relevant activities. To evaluate the students, teachers need not only a single form of assessment but also multiple forms to be conducted. Those forms of performance cover three domains namely cognitive, psychomotor, and affective in similar portion. An authentic assessment 
requires the learner to perform something in a real and meaningful situation. In broader concepts, authentic assessment requires the students to show their real ability.

Based on preliminary research at State Junior High School 1 Padang on March 2017, it is known that English teachers at grade IX are applied Curriculum 2013. The speaking subject was thought integrated with other skills while in assessing students' speaking activities the teacher had used some kinds of authentic assessments such as role play, presentation, guessing game and small group discussion. However based on the result of interview with one of the teacher at State Junior High School 1 Padang, she said that in assessing students speaking skill, she used the rubric that classified the students' ability into good, very good and excellent. Related to students speaking ability at State Junior High School 1 Padang it is known that the students had already confident in practice English and guessing game is the one to be applied in order to achieve better description of the students in speaking activities.

This study proposes to develop a guessing game as an authentic assessment for speaking. It is expected that assessment in authentic assessment meets with students needs effectively. In addition, through this research, it is hoped the guessing game could be applied by teacher appropriately in assessing speaking skill at State Junior High School 1 Padang. This school has been chosen by considering various reasons.

\section{METHOD}

This research is a research and development ( $R$ and $D)$ which uses ADDIE model which consist of five phases namely: analyze, design, develop, implement and evaluate. Firstly, it will be started by analyzing the needs from the students by giving questionnaire.

There are five phases will be conducted in this research. It is started by analyzing the need analysis on authentic assessment for speaking skill and ended by evaluating the assessment through perception of the users. Completely, those phases are presented as follows: Analyze, design, develop, implementation, and evaluation

The respondents of this research were 2 English teachers and 32 students grade IX at State Junior High School 1 Padang academic year 2016-2017. Researcher will take one class to be respondents of this research. Researcher have chosen 32 students as respondents by using purposive sampling technique where the respondents were selected by the purpose of research. Students who have learned speaking chosen as the respondents. Besides, the teachers have been chosen as respondent because they have been applying several speaking assessments. There are four kinds of instruments utilized for obtaining the data namely: questionnaire sheet, interview guideline, validation checklist and practicality checklist.

The data on instruments are analyzed quantitatively and qualitatively. Quantitative data, data from questionnaire sheet and validation checklist, are analyzed by using descriptive statistics to get the average and percentage result.

\section{FINDING AND DISCUSSION}

Authentic assessment facilitates students to be an active learner during teaching learning process. Authentic assessment has multiple forms, not merely one form. It gives much opportunity for students to practice their skill and ability in several ways. Then, authentic assessment has scoring rubric. Scoring rubric explains detail criteria that would be obtained in an assessment. Teachers also get ease in scoring their students' performance, since scoring rubric stated clear and concise narration.

There is no single model on assessing speaking, since authentic assessment basically facilitates various models. By having various model, students get broaden chance to develop their ability. Moreover, students mostly want communicative assessment model. Communicative activity means student get much chance to speak, to elaborate, to interact their idea and opinion one to another student such using guessing game. Teachers only as facilitators who facilitates students to explore their creativity over and over. In line with communicative activity.

Guessing games has been chosen by teachers and students as an applicable and suitable assessment. Basically, guessing game is the commonest assessment activity for students at lower level such as junior high school. Students try to tell describe people/ animals/ things to their friends, then the other friends try to guess the presenter describe.

There are several aspects in validation checklist such as selection of assessment models, relevance of assessment model to teaching instructional, language use, writing mechanism, and the suitability of scoring rubric. There are several suggestions from the expert to the researcher related to the models. Researcher examined deeply every suggestion in order to improve the authentic assessment models. Developing phase needs some revision almost for every phase.

In general, all the experts agreed that the models of authentic assessment were valid. There are five points that have been validated by experts. They are: selection of assessment models, relevance of the models, language use, writing mechanical and structure, and the suitability of the scoring rubric.

Guessing game is reasonable, since students need assessment that can support them speak communicatively and interactively. Besides, the models were simple, relevant, interactive and contextual to students' knowledge level. Then, the score relevance of assessment model toward teaching objectives was valid. It means that the authentic assessment models for speaking skill are relevant and suitable to teaching objectives in the curriculum. Next, language use of the models was categorized into valid. Language that used to write the models was appropriately understandable and readable. Last, the suitability of scoring rubrics toward assessment models was categorized into valid. The result of validity is reasonable since each of models has own 
scoring rubric that can be used by teachers in assessing students' speaking skill. Each of scoring rubric is valid for the model. Researcher states clear and concise scoring rubric in every models of authentic assessment. In assessing, scoring rubric is important point to be considered by teachers.

To develop a scoring rubric, researcher used analytical scoring rubric. There are several important criteria in assessing speaking as stated by Brown (1994:172-173) namely: pronunciation, grammar, vocabulary, fluency, and comprehension. Pronunciation goes for acceptability of the sound toward a letter. Sound is important key on pronunciation, correct pronunciation drives to the correct meaning. Vocabulary is basic element in speaking. Speaking means producing some words or letters. It is almost impossible to speak without saying a word. Vocabulary means the appropriate diction which is used in communication. Without having a sufficient vocabulary, people cannot communicate or express effectively their ideas both oral and written form.

The last research question is about the feasibility of the developed authentic assessment models for speaking skill at grade IX Junior High School 1 Padang. Mostly they are interested to these assessment models. By using this model, they wanted to speak English. The result of practicality checklist showed that the students response was practical. Their perception toward these products were, enjoy, communicative, easy and simple to practice in classroom. Besides, teachers gave positive response to these models. These models are practical to be applied in assessing speaking skill.

There are several components in the models such as: relevance model toward teaching instructional, the ease of using the model, benefit of the models, language use, completeness of the media, and the compliance of time to apply the models. The result of relevance model toward teaching instructional was practical. It means, the models of authentic assessment linked with English instruction for Junior High School. The students can speak English for their daily life. The ease of using the model was categorized into very practical. These models are easy to be applied in the classroom. Besides, they also easy to be constructed by teachers. Benefit of the models was categorized into very practical. These models give students much opportunity to develop their speaking skill. Students can communicate interactively among the students.

\section{CONCLUSION AND RECOMMENDATION}

Based on the result and discussion, it is safe to say most of the students want the assessment must be fun, must be easy to do, must use sound, and cassette, can encourage students to be active learner, and must be used in the comfortable and funny situation. Students should be assessed to develop their speaking skill.

This suggestion goes along the positive point of view suggesting that guessing game is very useful and it could help teacher to assess in finding and improving students' speaking skill. To conclude, based on the findings of this study it is recommended that EFL teachers use guessing game as one of authentic assessment in speaking skill.

\section{References}

Brown, H, Douglas. (2001). Teaching by Principles: An Interactive Approach to Language Pedagogy. $2^{\text {nd }}$ Edition. San Francisco: Longman.

Brown, H, Douglas. (2004). Language Assessment Principles and Classroom Practices (Second Edition). New York: Pearson Education, Inc.

Callison, Daniel. (1998). Authentic Assessment. Journal School Library Media Activities Monthly. Indiana University: Bloomington.

Choate, S. Joyce, and Susan S Evans. (1992). Authentic Assessment of Special Learner: Problem and Promise. Education Journal Northeast Louisiana University.

Depdiknas. (2006). Rancangan Penilaian Hasil Belajar. Jakarta: Depdiknas

Dick, W and Carey, L. (2009). The Systematic Design of Instruction (4 ${ }^{\text {th }}$ edition). New York, NY: Harper Collin.

Finch, A. E. (2002). Authentic Assessment: Implication for EFL performance testing in Korea. Secondary Education Research.

Harris, D. P. (2005). Testing English as a Second Language. Bombay: Tata-McGraw Hill \& Co. Ltd.

Johnson, David, W and Roger Johnson. (2002). Meaningful Assessment: A Manageable and Cooperative Process. Boston: Allyn and Bacan.

Kamen, Michael. (1996). A Teacher's Implementation of Authentic Assessment in an Elementary Science Classroom. Journal of Research in Science Teaching vol. 33, no. 8, pp. 859-877.

Lines, Christi. (1994). Authentic Assessment at the middle level. Middle School Journal. University of Northern Iowa, Nashua, Iowa.

Lombardi, M. Marilyn. (2008). Making the Grade: The Role of Assessment in Authentic Learning. Journal Educause Learning Initiative.

Luoma, Sari. (2009). Assessing Speaking. Cambridge: Cambridge University Press.

McKay, Penny. (2006). Assessing Young Language Learner. Cambridge: Cambridge University Press. 